\title{
Research Design Archaeological Site 41KE93 Kendall County, Texas
}

Wayne C. Young

Follow this and additional works at: https://scholarworks.sfasu.edu/ita

Part of the American Material Culture Commons, Archaeological Anthropology Commons, Environmental Studies Commons, Other American Studies Commons, Other Arts and Humanities Commons, Other History of Art, Architecture, and Archaeology Commons, and the United States History Commons

Tell us how this article helped you.

This Article is brought to you for free and open access by the Center for Regional Heritage Research at SFA ScholarWorks. It has been accepted for inclusion in Index of Texas Archaeology: Open Access Gray Literature from the Lone Star State by an authorized editor of SFA ScholarWorks. For more information, please contact cdsscholarworks@sfasu.edu. 


\section{Research Design Archaeological Site 41KE93 Kendall County, Texas}

\section{Licensing Statement}

This is a work produced for the Texas Department of Transportation (TxDOT) by the report producer. TxDOT and the report producer jointly own all rights, title, and interest in and to all intellectual property developed under TXDOT's contract with the report producer. The report may be cited and brief passages from this publication may be reproduced without permission provided that credit is given to both TxDOT and the report producer. Permission to reprint an entire chapter, section, figures or tables must be obtained in advance from either the Supervisor of the Archeological Studies Branch, Environmental Affairs Division, Texas Department of Transportation, 125 East 11th Street, Austin, Texas, 78701 or from the report producer. 
RESEAROH DESIGN

AROHAEOLOGICAL SITE 41KE93

KENDALL COUNTY,TEXAS

Wayne $\stackrel{\text { By }}{\text { C. Young }}$

State Department of Highways and Public Transportation Austin, Texas

October, 1985 


\section{RESEARCH DESIGN \\ ARCHAEOLOGICAL SITE 41KE93}

Very little information is available regarding Site 41KE93. The site is located adjacent to FM 474, approximately 8.7 miles northeast of Boerne, in Kendall County, Texas. It is situated on a small finger of land some 100 meters south of the Guadalupe River at Ammans Crossing and is bordered to the west by Sebinas Creek. Two hearths and a scatter of lithic debris were observed on the surface at the time the site was recorded, but no temporal or cultural indicators have, as yet, been found. From surface indications within the project right-of-way, the portion of the site available for the present study is limited to an area of about 100 by $50 \mathrm{ft}$. (the $1 \mathrm{imits}$ of the SDHPT jurisdiction).

Testing operations will begin with a thorough surface examination of the site in order to locate any exposed concentrations of cultural materials. The exposed hearths will be exposed and documented with drawings and photographs. A series of 2 meter squares will be excavated along the right-of-way fence from the area of the hearths toward the river in order to determine the depth of the culture-bearing deposits and to evaluate the integrity of the cultural zones. The goal of the testing phase shall be to evaluate the site for potential State Archeological Landmark status as well as to delineate the temporal, cultural, and spatial limits of the site.

Areas with the greatest soil and cultural depths will be chosen for more extensive excavation as the components, if present, are more likely to be isolated in deeper soils. Plans are to expose larger excavation areas if 
testing results warrant more detailed investigation. These areas will be excavated in 4 meter blocks quartered into 2 meter squares and dug in either 5 or $10 \mathrm{~cm}$ levels, depending upon the results of the previous testing. All hand-excavated matrix will be passed through 0.25 in. hardware cloth in order to recover lithic and organic remains by square and level. Soil samples will be taken for potential special studies such as pollen analysis or snail studies.

Research goals will center on a determination of the age and cultural affiliation of the site as well as a determination of site function, with an emphasis on revealing the exploitative strategies through time. Hopefully preservation conditions will favor the recovery of organic materials and a partial understanding of which materials were being exploited at the site can be obtained. The cultural history of the site and of Kendall County will also be explored through an analysis of material recovered through these investigations. 